Article

\title{
Insect Marks on Bones from La Guillerma Archaeological Locality (Salado River Depression, Buenos Aires, Argentina)
}

\author{
Paula D. Escosteguy ${ }^{1, *(\mathbb{D}}$, Alejandro E. Fernandez ${ }^{1}(\mathbb{D})$ and María Isabel González ${ }^{2}$ (D) \\ 1 CONICET, Instituto de Arqueología, Facultad de Filosofía y Letras, Universidad de Buenos Aires, \\ Buenos Aires PC C1002ABE, Argentina; alejandro.fernandez@uba.ar \\ 2 Instituto de Arqueología, Facultad de Filosofía y Letras, Universidad de Buenos Aires, \\ Buenos Aires PC C1002ABE, Argentina; igonzale@filo.uba.ar \\ * Correspondence: pdescosteguy@uba.ar
}

check for updates

Citation: Escosteguy, P.D.; Fernandez, A.E.; González, M.I. Insect Marks on Bones from La Guillerma Archaeological Locality (Salado River Depression, Buenos Aires, Argentina). Quaternary 2021, 4, 45. https:// doi.org/10.3390/quat4040045

Academic Editors: Juan Rofes, Janine Ochoa and Emmanuelle Stoetzel

Received: 14 September 2021 Accepted: 1 December 2021 Published: 16 December 2021

Publisher's Note: MDPI stays neutral with regard to jurisdictional claims in published maps and institutional affiliations.

Copyright: (c) 2021 by the authors. Licensee MDPI, Basel, Switzerland. This article is an open access article distributed under the terms and conditions of the Creative Commons Attribution (CC BY) license (https:/ / creativecommons.org/licenses/by/ $4.0 /)$.

\begin{abstract}
The La Guillerma archaeological locality is located in the northeast sector of Buenos Aires province (Argentina). Two of its sites (LG1 and LG5), dated between ca. 1400- and 600-years BP, have a great amount of faunal remains including deer, rodents, fish and small birds that are subjected to taphonomic agents and processes (e.g., weathering, manganese, roots). Previous studies have shown osteophagic behaviour in different insects (e.g., Coleoptera, Blattodea). In this paper, we evaluate their incidence on La Guillerma faunal assemblage. We performed an analysis on marks that were identified in bone remains of various taxa and applied the criteria for identifying bone alteration by insects (i.e., by measuring each trace and comparing them with the types of insect marks described in the literature). Fifteen specimens (LG1 = 6 and LG5 =9) exhibited different types of modifications (e.g., pits with striae in base, pits with emanating striae, striations) that are related to the action of insects. Although the proportion of affected bones is low in relation to the total sample, we highlight our study as the first detailed analysis of insect marks on archaeological bones from Argentina. We also emphasize the significance of addressing insect-produced modifications on Argentinean archaeological sites.
\end{abstract}

Keywords: taphonomy; faunal remains; pampas; late Holocene; bone damage

\section{Introduction}

Many taphonomic processes may modify animal carcasses and bones between the time of death and the burial (e.g., [1-3]). Also, some parasites can modify bone tissue during the life of the animal $[4,5]$. The analysis of surface modifications on bone remains and the recognition of the different agents involved have exponentially grown during the last few decades. This identification is primarily supported by the experience observing fossil and modern sites and by experimental studies (e.g., [1-3]). However, insects have not been considered as a major taphonomic agent until recently [6-10]. In fact, insect damage has often been inferred in the fossil record with no comparative data. Thus, laboratory experiments on this issue require urgent attention $[2,11]$.

Recent studies have shown that analysis of osteophagus insects had great importance in the interpretation of the bioarchaeological record since their damage could be misinterpreted either as cultural modifications or as pathologies $[8,12,13]$. Other studies emphasize the considerable contribution that insect activity plays in the site formation processes and the alteration or destruction of faunal remains [14].

The aim of this article is to assess the incidence of insects as taphonomic agents that affected the archaeofaunal assemblages of the La Guillerma archaeological locality and to evaluate their importance as a formation process in sites from the Salado River Depression. This area is located in the Argentinean pampas and is drained by the middle and lower course of the river (Figure 1). The chronological dates situate the occupations in the late Holocene, between 2400- and 400-years BP, and the archaeological contexts show 
a varied repertoire of technological and subsistence remains [15-17]. Based on the use of resources, the settlement pattern and technology, these groups have been characterized as hunter-gatherer-fishermen with pottery [18].

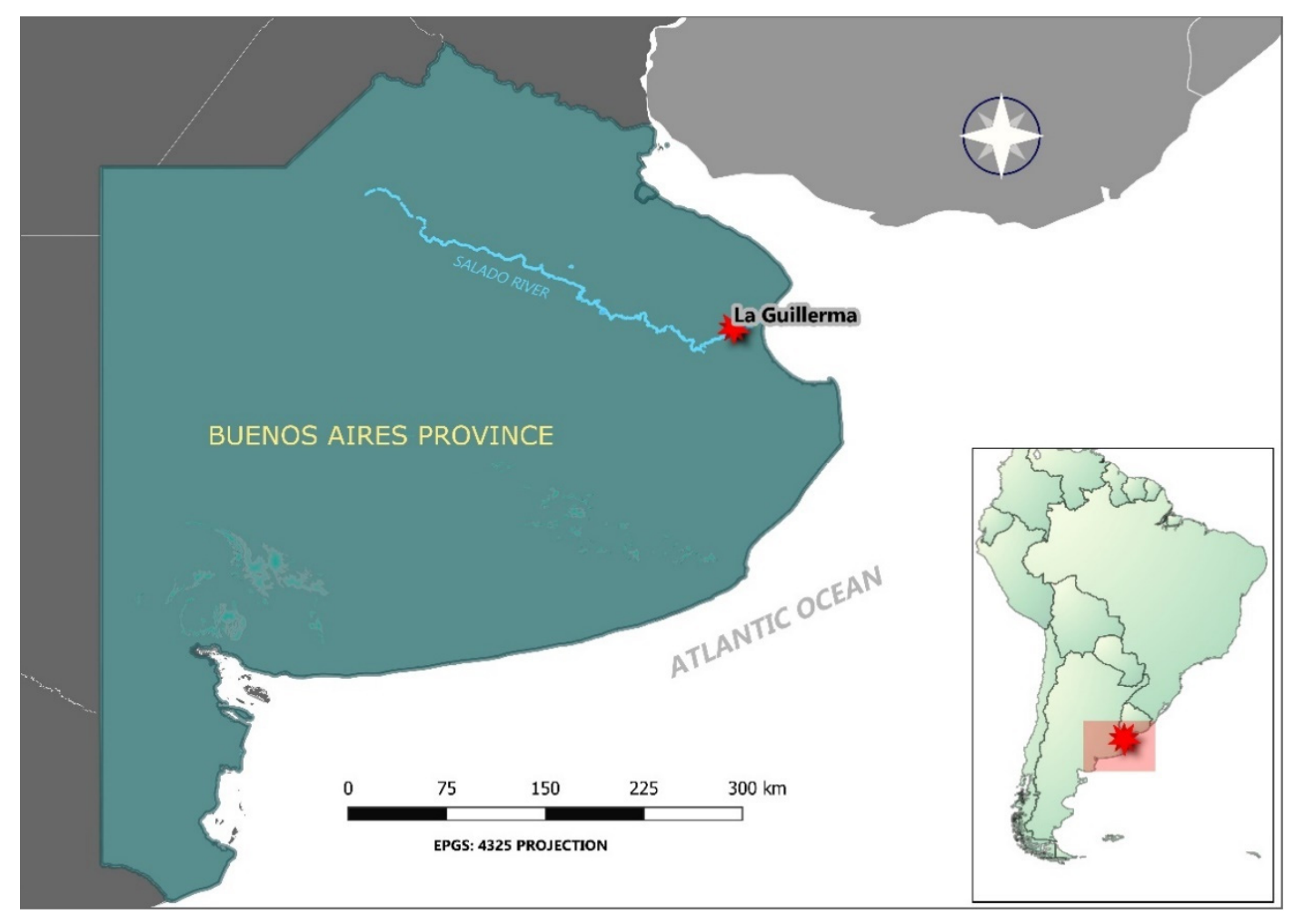

Figure 1. Location of La Guillerma archaeological locality.

\section{Background}

\subsection{Research Area}

The Salado River Depression is located northeast of the province of Buenos Aires and has a temperate and humid climate. Its hydrographic network, formed by the Salado River and several shallow lakes, configures a wetland and lentic environment [19]. To the northeast of the river there are soft hills covered by grasslands. Near the northeast edge, there are talares (Celtis tala) arranged as isolated crescent-shaped archipelagos [20]. Although climatic fluctuations have been detected in several regions of southern South America during the late Holocene, the palaeoenvironmental, palaeoclimatic and palaeoecological reconstruction of the pampas is still tentative and yet not calibrated for interpretation on an archaeological scale [21].

An interdisciplinary study on the Late Quaternary of Salado River middle basin [22], which considered stratigraphical, geomorphological and paleontological data, proposed a model of palaeoenvironmental reconstruction that distinguishes dry conditions between 8000 and 3000 years BP, followed by a gradual return towards wet conditions from 3000 years BP to present time. This last period includes a moment of water deficit conditions circa 1800 years BP, represented by a short depositional hiatus [22]. The data available for the first stages of European arrival indicate more arid conditions, which correspond to the Little Ice Age (approximately 1450-1850 AD). After this, a more humid period followed. During the 19th and 20th centuries, rains and floods became more frequent [23].

The La Guillerma archaeological locality was inhabited during the late Holocene and includes five sites, distributed over a series of elevations along the left margin of the Salado River, at approximately $40 \mathrm{~m}$ from its bed. LG1 and LG5 sites (which are $100 \mathrm{~m}$ apart) have a great abundance of ceramic sherds, stone artifacts, and plant and animal remains $[15,17,18]$. The dates made on these materials showed human occupations between 
ca. 1200- and 600-years BP for LG1 and ca. 1400- and 660-years BP for LG5 (for further information, see Table 1 and Figure 3 in [15]). The soils show a marked horizonation, with a clay-sandy silt texture, and the $\mathrm{pH}$ of the surface horizons is lightly acid. However, LG5 has better internal drainage conditions that favours the bone remains conservation [18]. These are shallow sites, given that archaeological remains are predominantly deposited in the first $30 \mathrm{~cm}$ of the soil and are subjected to pedogenetic processes. Among them, a high biological activity including the action of roots, burrowing animals, and microfauna causes the dispersion or concentration of materials [18,24].

Regarding the archaeofaunal record, mammals include deer (Blastocerus dichotomus and Ozotoceros bezoarticus), rodents (coypu (Myocastor coypus), guinea pig (Cavia aperea), tucu-tucu (Ctenomys sp.), among others) and undetermined armadillos. Among fish, we identified catfish (Rhamdia quelen), tiger fish (Hoplias argentinensis), mullet (Mugil platanus) and black drum (Pogonias courbina). Small birds, such as Eudromia elegans, Fulica sp. and other undetermined Anatidae are also predominant. The estimations of NISP were: LG1 = 2486 and LG5 = 6049 [16,18].

Taphonomic analyses carried out on the archaeofaunal assemblages, following the criteria described by Lyman [3] and Fernandez-Jalvo and Andrews [2], showed the action of different agents and processes that altered bones from both sites but in low proportion. In LG1, roots affected $5.3 \%(n=132)$ whereas the presence of manganese oxide deposits was observed on $5.39 \%(n=134)$. In this site, low stages of weathering (sensu Behrensmeyer [25]) were registered on $6.31 \%(n=157)$ of the specimens, being more present on big mammals bones. In less percentages, we registered the action of rodents $(0.68 \%, n=17)$ and carnivores $(0.12 \%, \mathrm{n}=3)$. In LG5, modifications generated by roots (decolouring and dendrite marks) were observed on $2 \%$ of bones $(n=121)$. In similar rates $(2.11 \%, n=128)$, manganese produced dark spots. In greater proportion $(3.38 \%, n=205)$, we observed weathering, mainly stages 1 and 2 (sensu Behrensmeyer [25]). Only one specimen displayed a puncture made by carnivore $(0.01 \%)$, and $0.43 \%(n=26)$ of bones exhibited traces generated by rodents. Sometimes, these marks obliterated evidence of anthropic manipulation, which is also in low proportion [18,26-28]. In spite of the recognition of anthills and insect burrows during excavations, along with changes in colour and texture in discrete sectors of the sedimentary context, no insect marks had been identified.

\subsection{Insects as Taphonomic Agents}

Insects are important soil formation agents, due to their colonizing capacity in a variety of substrates and their ability to rework sediments and use organic matter as raw material to make nests [29]. Ants, termites and other taxa can mix and modify soil and, in the process, affect an archaeological site and its content [30]. In particular, McBrearty [31] noted that termite bioturbation activity in African sites modified the soils' properties and produced pseudofeatures as well as the movement of materials.

Apart from insect remains and associated features, their presence can also be detected by the modifications made on the bone record. Recent studies have shown that analysis of osteophagus insects had great importance in the interpretation of the bioarchaeological record, since their damage could be misinterpreted as cultural modifications or as pathologies $[8,12]$. Other studies emphasize the contribution that insect activity plays in the site formation processes and the alteration or destruction of faunal remains [14] and its utility to reconstruct past environmental and climatic conditions [6,32].

A great variety of insects can produce damage to bones in many ways. Among these, beetles (Dermestidae, Tenebrionidae and Scarabaeoidea), termites (Kalotermitidae and Termitidae), ants (Formicidae), moths (Tineidae), blowflies (Calliphoridae), mayflies (Polymitarcyidae) and cockroaches (Blattidae) have been registered in Buenos Aires province $[33,34]$.

Dermestid beetles can produce striations, extensive pitting, and edge gnawing [14]. They can also make deep conical perforations when penetrating into the bone [7]. Holden et al. [35] found in an experiment that both dermestid and tenebrionid larvae leave dif- 
ferent kinds of damage in different stages of carcass decay, so they conceive that other beetle families may modify bone as well. Also, several researchers have described either archaeological or palaeontological examples of bone alteration by termites $[6,10,36,37]$. Experimental studies have shown that they produce striations, boreholes, edge gnawing, pits with smooth base, pitting, destruction, smoothed abrasion, polish, surface removal and surface coating. The last two types of damage are more frequent [14]. Cockroaches have been noted as another potential agent of bone alteration, as they colonize corpses. Parkinson [32] made experiments with the species Periplaneta americana, which resulted in three types of modification, namely discolouration, destruction and gnawing.

The specific climatic requirements for each kind of insect have also been addressed. The cosmopolitan species Dermestes maculatus needs a minimum temperature of $20^{\circ} \mathrm{C}$ to feed and is more active during the warmer months [32]. In regards to termites, Kalotermitidae need very little moisture to survive, while Termitidae live underground since the soil has the capacity to hold water for a long period and keep the colony moist [38]. Trinervitermes trinervoides, a species of this last family, shows an increased activity during autumn and spring [6]. Cockroaches, on their part, have adapted to highly diverse thermal climatic ranges but prefer a warm and moist environment [32].

Other taxa have been noted to presumably modify bone. Go [39] analyzes a case where a colony of ants nested inside human bone and modified it. Moth larvae tunneling is common on horns and antlers [2], though it has not been registered on bone. Larval blowflies may also produce small bores when they create pupation chambers [6,35]. Finally, mayfly nymphs make U-shaped burrows on wood, and similar traces reported in bone have been attributed to them [7].

\section{Materials and Methods}

The zooarchaeological assemblages from LG1 and LG5 are curated at the Instituto de Arqueología (Facultad de Filosofía y Letras, Universidad de Buenos Aires), where reference collections of diverse taxa (birds, mammals and fishes) are also available. These have been used for taxonomic and anatomical identification. As stated in the Background section, the samples were LG1 $=2486$ and LG5 $=6049$ and several taphonomic agents, and processes such as weathering, rodents, and roots of different sizes have modified the faunal assemblages $[16,26,27]$. However, fifteen specimens (six from LG1 and nine from LG5) displayed traces that had not been recognized previously.

We examined these marks using a high-intensity light from a two-led illuminator and a low-power binocular microscope (Zeiss STEMI 305) with a magnification up to $40 \times$. We took note of their position on each specimen and measured them using the tools provided by ZEN Blue edition software. We measured the diameter of holes, bores and pits. On those specimens where the marks overlapped, we registered the length of the affected area.

We considered the proposals of Pirrone and collaborators [40], Parkinson [11,32] and Backwell and co-authors $[6,14]$ to analyze insect traces. For the description of the general morphology of traces, we distinguished between pits, holes, chambers, tubes/bores, furrows and grooves/striae. To broaden the analysis of traces, we followed Backwell and co-authors' criteria and considered different types of pits: pit with striae in base, pit with smooth base, and pit with emanating striae [14]. We also regarded other modification features such as pitting, etched surface, destruction, dissolution and the presence of surface coating/discolouring [6,14,32].

\section{Results}

After our analysis, the fifteen bone specimens displayed, at least, one of the traces associated with insect activities (Table 1, Figure 2). These values represent respective low $\%$ NISP: $\mathrm{LG} 1=0.24 \%$ and LG5 $=0.14 \%$. 
Table 1. Traces on bones from LG1 and LG5 sites. * Diameter; ${ }^{* *}$ Affected area.

\begin{tabular}{|c|c|c|c|c|c|c|}
\hline Site & $\#$ & Taxa & Bone & Type of Modification & Measure & Observations \\
\hline \multirow{10}{*}{ LG1 } & \multirow{3}{*}{201} & \multirow{3}{*}{ Mammalia } & \multirow{3}{*}{ Long bone } & Pit with emanating striae & $4.25 \mathrm{~mm}$ * & \multirow{3}{*}{ Figure 10} \\
\hline & & & & Surface residue & - & \\
\hline & & & & Etched appearance & - & \\
\hline & 5 & Mammalia & Long bone & Striations & $4.89 \mathrm{~mm}^{* *}$ & $\begin{array}{l}\text { Edge gnawing around } \\
\text { nutrient foramen. } \\
\text { Figure } 8 \mathrm{~B}\end{array}$ \\
\hline & 340 & Mammalia & Long bone & Pit with striae in base & $2.41 \mathrm{~mm}$ * & Figure 3C \\
\hline & \multirow{2}{*}{4} & \multirow{2}{*}{ Cervidae } & \multirow{2}{*}{ Long bone } & Hole & $4.06 \mathrm{~mm}$ * & \multirow{2}{*}{$\begin{array}{c}\text { A smooth-based boring } \\
\text { Figure } 9 \mathrm{~B}\end{array}$} \\
\hline & & & & Pit with striae in base & $3.28 \mathrm{~mm}^{*}$ & \\
\hline & 217 & $\begin{array}{l}\text { Ozotocerus } \\
\text { bezoarticus }\end{array}$ & Tibia & Hole & $2.66 \mathrm{~mm} *$ & $\begin{array}{l}\text { A smooth-based } \\
\text { boring. } \\
\text { Figure 9C }\end{array}$ \\
\hline & \multirow{2}{*}{362} & \multirow{2}{*}{$\begin{array}{l}\text { Ozotocerus } \\
\text { bezoarticus }\end{array}$} & \multirow{2}{*}{ Phalange 1} & Bore & $2.93 \mathrm{~mm}$ * & \multirow{2}{*}{$\begin{array}{l}\text { Bore hole. } \\
\text { Figure 9A }\end{array}$} \\
\hline & & & & Etched appearance & - & \\
\hline \multirow{19}{*}{ LG5 } & \multirow{3}{*}{205} & \multirow{3}{*}{ Aves } & \multirow{3}{*}{$\begin{array}{l}\text { Long bone } \\
\text { diaphysis }\end{array}$} & Pit with striae in base & $2.68 \mathrm{~mm}^{*}$ & \multirow{3}{*}{$\begin{array}{l}\text { Foraging area. } \\
\text { Overlapping of marks. } \\
\text { Affected post } \\
\text { weathering. }\end{array}$} \\
\hline & & & & Pit with emanating striae & $5.12 \mathrm{~mm} * *$ & \\
\hline & & & & Striations & - & \\
\hline & \multirow{3}{*}{220} & \multirow{3}{*}{ Aves } & \multirow{3}{*}{ Femur } & Pit with emanating striae & $3.52 \mathrm{~mm} *$ & \multirow{3}{*}{$\begin{array}{l}\text { Affigure } 5 \text { ost } \\
\text { weathering. } \\
\text { Figure } 4 \mathrm{~A}\end{array}$} \\
\hline & & & & Surface residue & - & \\
\hline & & & & Striations & & \\
\hline & \multirow{2}{*}{2005} & \multirow{2}{*}{ Mammalia } & \multirow{2}{*}{ Tibia } & Pit with striae in base & $2.90 \mathrm{~mm}^{*}$ & \multirow{2}{*}{$\begin{array}{c}\text { Overlapping of marks. } \\
\text { Figure 3B }\end{array}$} \\
\hline & & & & Etched appearance & - & \\
\hline & \multirow{2}{*}{3713} & \multirow{2}{*}{ Cavia aperea } & \multirow{2}{*}{ Femur } & Pit with striae in base & $2.81 \mathrm{~mm} *$ & \multirow{2}{*}{$\begin{array}{l}\text { Overlapping of marks. } \\
\text { Figure 3A }\end{array}$} \\
\hline & & & & Striations & - & \\
\hline & \multirow{3}{*}{1623} & Myocastor & & Pit with emanating striae & & Overlapping of marks. \\
\hline & & coypus & Humerus & Pit with striae in base & $4.73 \mathrm{~mm}^{* *}$ & $\begin{array}{l}\text { Fissure along the bone. } \\
\text { Figure } 6\end{array}$ \\
\hline & & & & Striations & & \\
\hline & 5332 & $\begin{array}{l}\text { Myocastor } \\
\text { coypus }\end{array}$ & Humerus & Pit with emanating striae & $3.38 \mathrm{~mm}$ * & $\begin{array}{l}\text { Striae on base. } \\
\text { Figure } 7\end{array}$ \\
\hline & 5519 & Myocastor & Radius & Pit with striae in base & $3.10 \mathrm{~mm}$ * & Overlapping of \\
\hline & & coypus & & Striations & - & $\begin{array}{c}\text { grooves. } \\
\text { Figure 3D }\end{array}$ \\
\hline & 5773 & Myocastor & Tibia & Pit with emanating striae & $2.67 \mathrm{~mm}^{*}$ & Figure 4B \\
\hline & & coypus & Hivia & Striations & - & \\
\hline & 14 & $\begin{array}{l}\text { Ozotocerus } \\
\text { bezoarticus }\end{array}$ & Humerus & Striations & $3.35 \mathrm{~mm} * *$ & $\begin{array}{c}\text { Overlapping of } \\
\text { grooves. Fissure along } \\
\text { the bone. } \\
\text { Figure 8A }\end{array}$ \\
\hline
\end{tabular}

Surface pit is the most frequent type of modification (Figure 2). It was recorded on mammals and bird bones. We distinguished between pits with striae in base (Figure 3) and pits with emanating striae (Figure 4). We identified the former type in two specimens from LG1 and five from LG5, while the latter category was displayed on one specimen from LG1 and five from LG5. The diameter of pits with striae in base ranged from $2.41 \mathrm{~mm}$ to $3.59 \mathrm{~mm}$. The pits with emanating striae are formed by multiple overlapping grooves that are radially arranged. Their diameter measured between $2.67 \mathrm{~mm}$ and $4.25 \mathrm{~mm}$. 


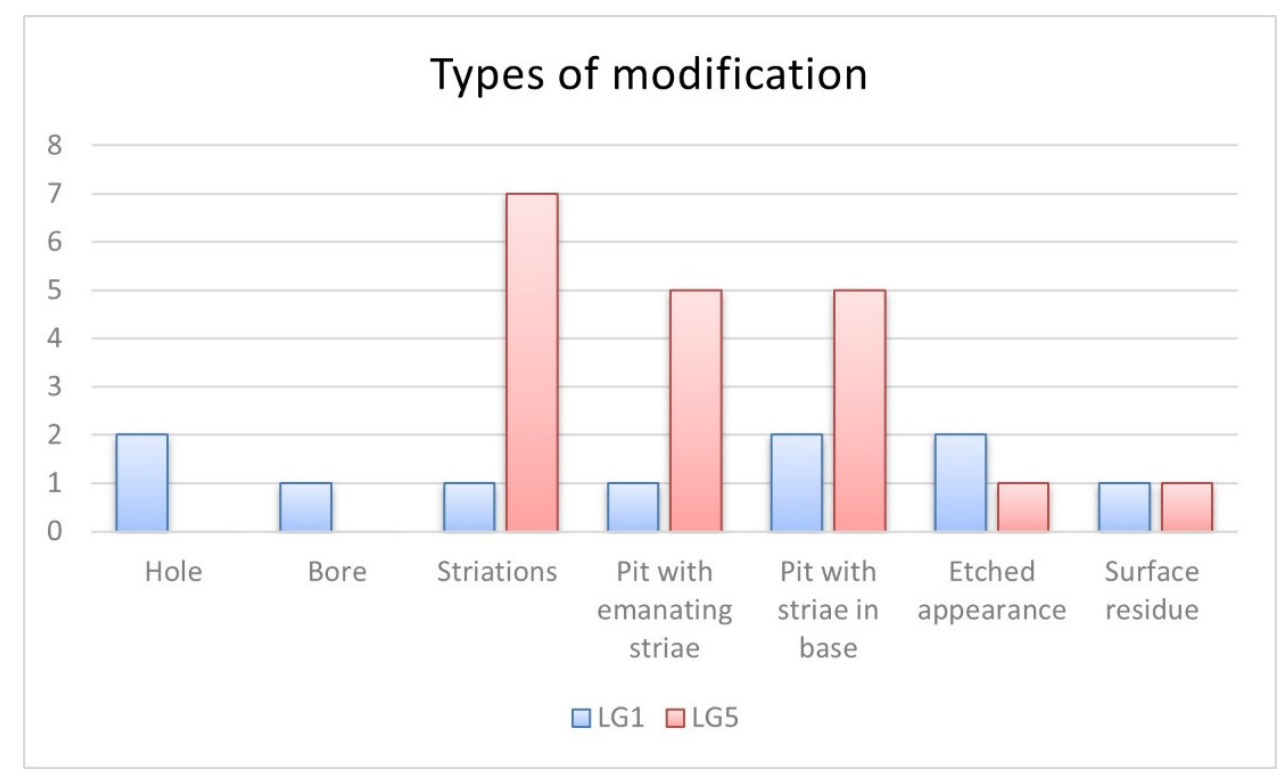

Figure 2. Types of modification on LG1 and LG5 sites.

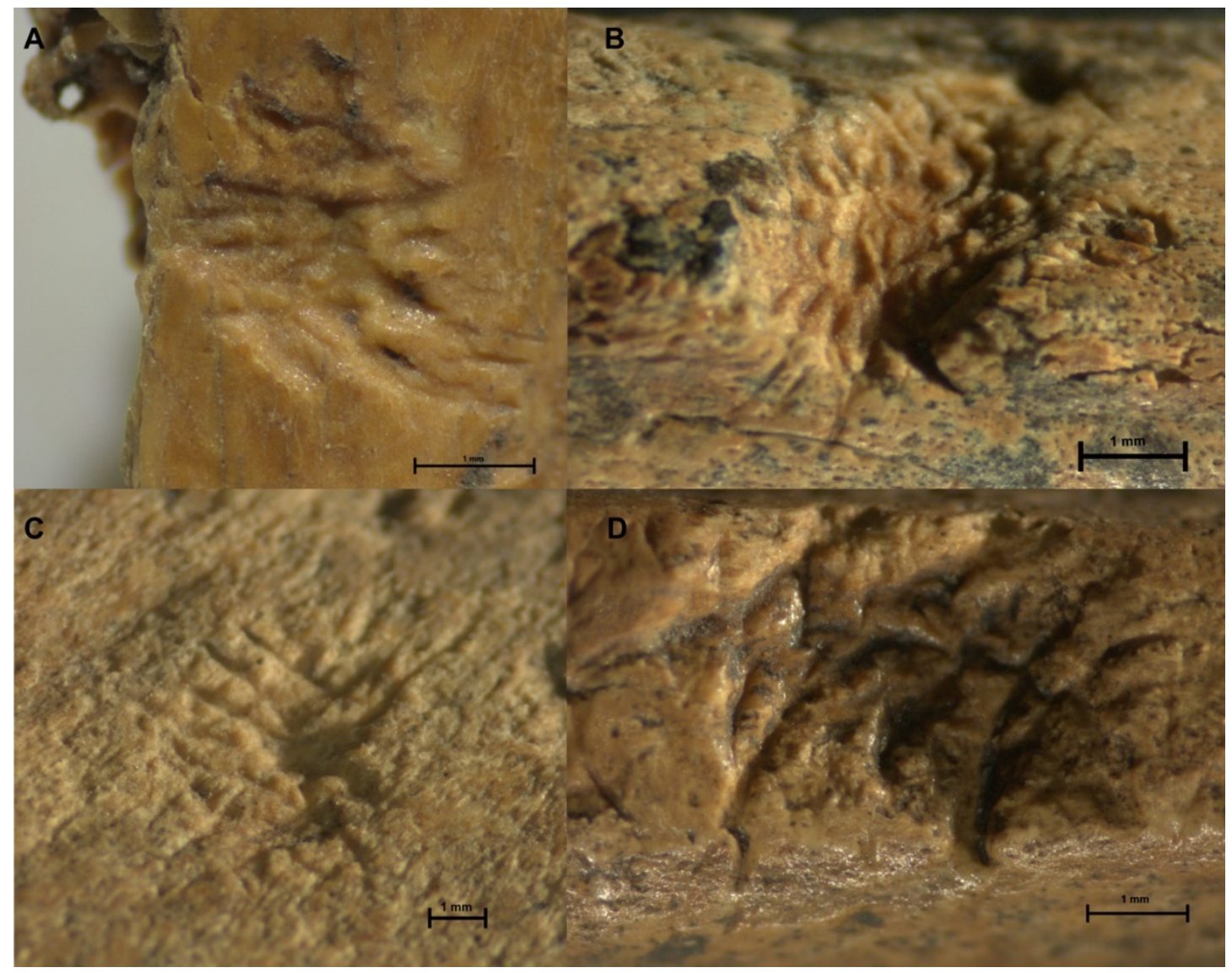

Figure 3. Pits with striae in base. (A) Pit on C. aperea's femur (Id. 3713). (B) Pit and etched appearance on a mammals' tibia (Id. 2005). (C) Pit on a fresh fracture surface (Id. 340). (D) Pit on a coypu radius (Id. 5519). 

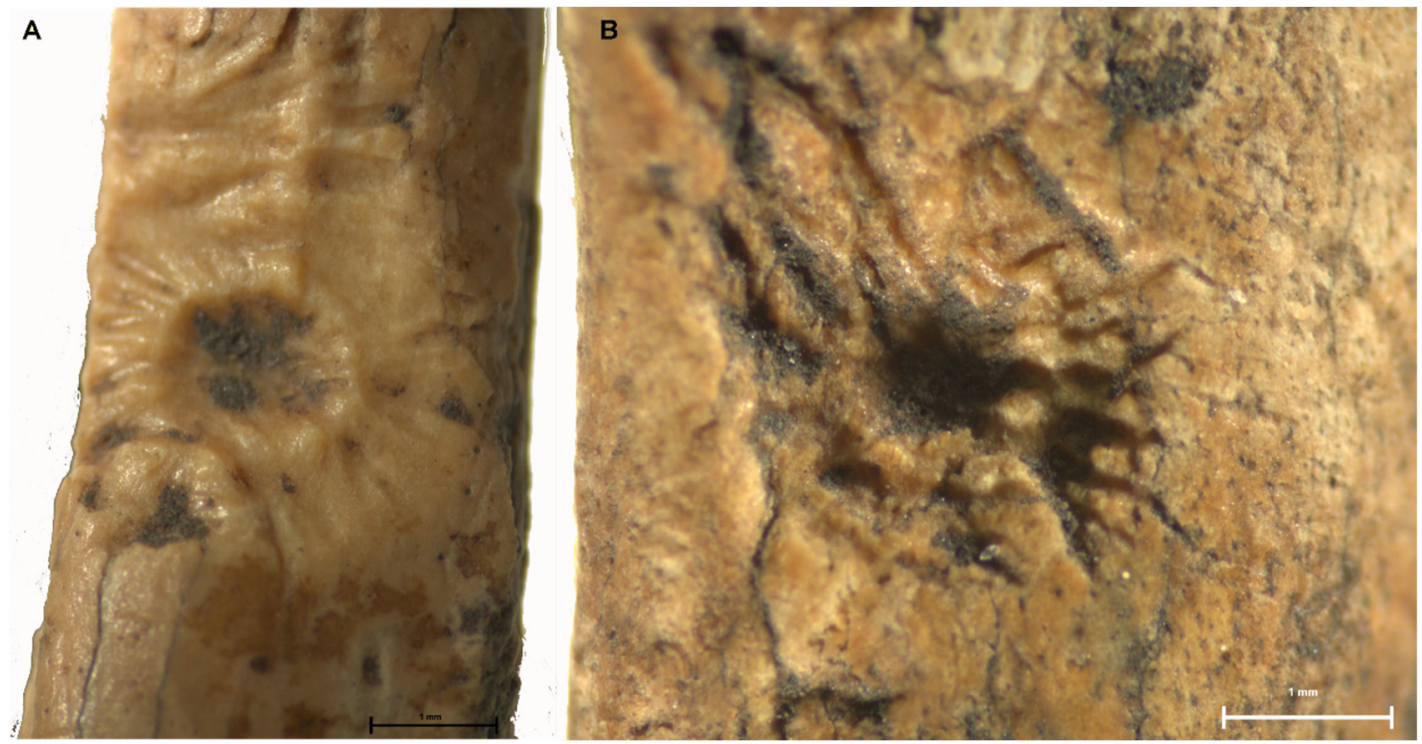

Figure 4. Pit with emanating striae. (A) Pit, multiple striations and residue on bird bone (Id. 220). (B) Deep pit on a coypus' tibia (Id. 5773).

Two specimens (Id. 205 and 1623) displayed both types of pits. One of them is a long bone of a small-sized bird (Id. 205). This diaphysis exhibits two modified sectors. In one of them, there is an area that displays a shallow pit with striae in base. In addition to this, there are multiple parallel and sub-parallel striations (Figure 5A). The other sector shows overlapping of pits with emanating striae along $5.12 \mathrm{~mm}$ (Figure 5B). These marks, composed of multiple grooves radially arranged around a cavity, seem to have been made after the exposure of the bone to aerial conditions; it exhibits weathering on the rest of the cortical surface but not over these marks. The other bone is a coypu's humerus (Id. 1623) that is longitudinally fissured. In its medial shaft, it displays the overlapping of at least a surface pit with striae in base and a pit with emanating striae. Besides these pits, there are clusters of randomly oriented sub-parallel striations within an area of $4.73 \mathrm{~mm}$. We highlight that these marks are previous to the crack, and their deepest part is along it (Figure 6A,B).

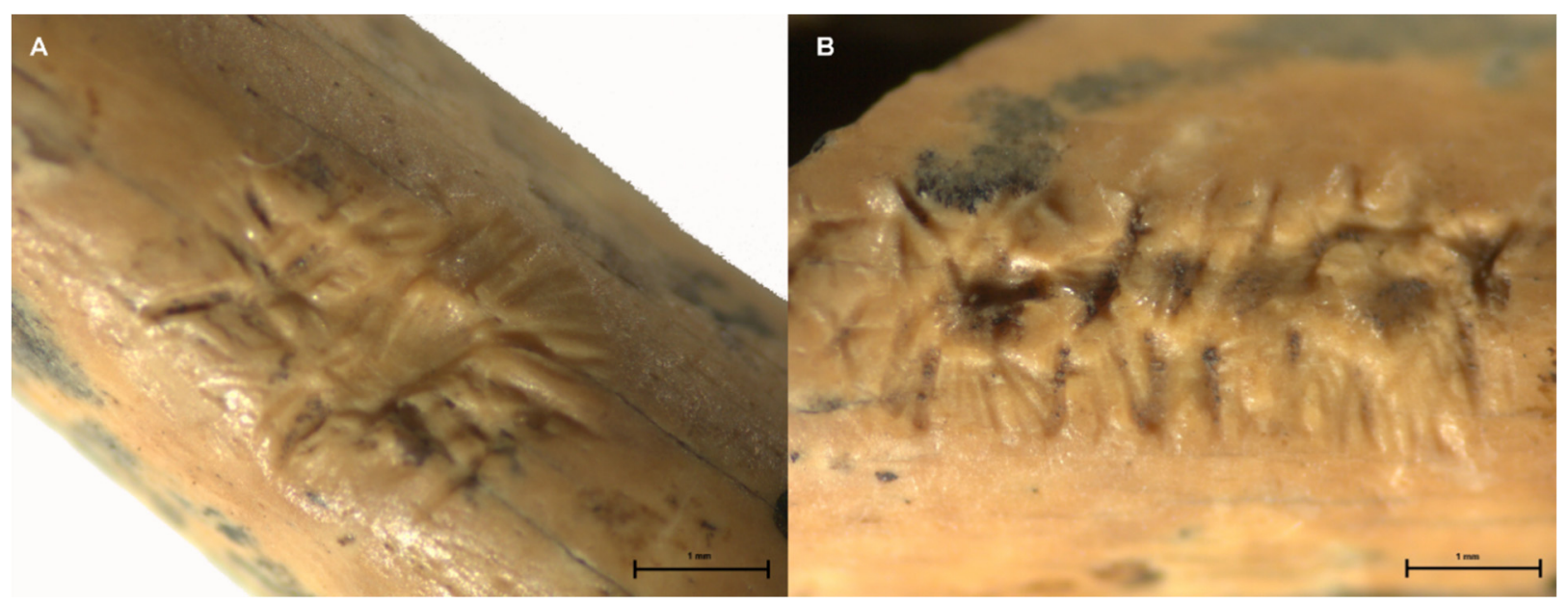

Figure 5. Pits on a bird bone (Id. 205). (A) Pit with striae in base and multiple striations. (B) Overlapping of pits with emanating striae. 


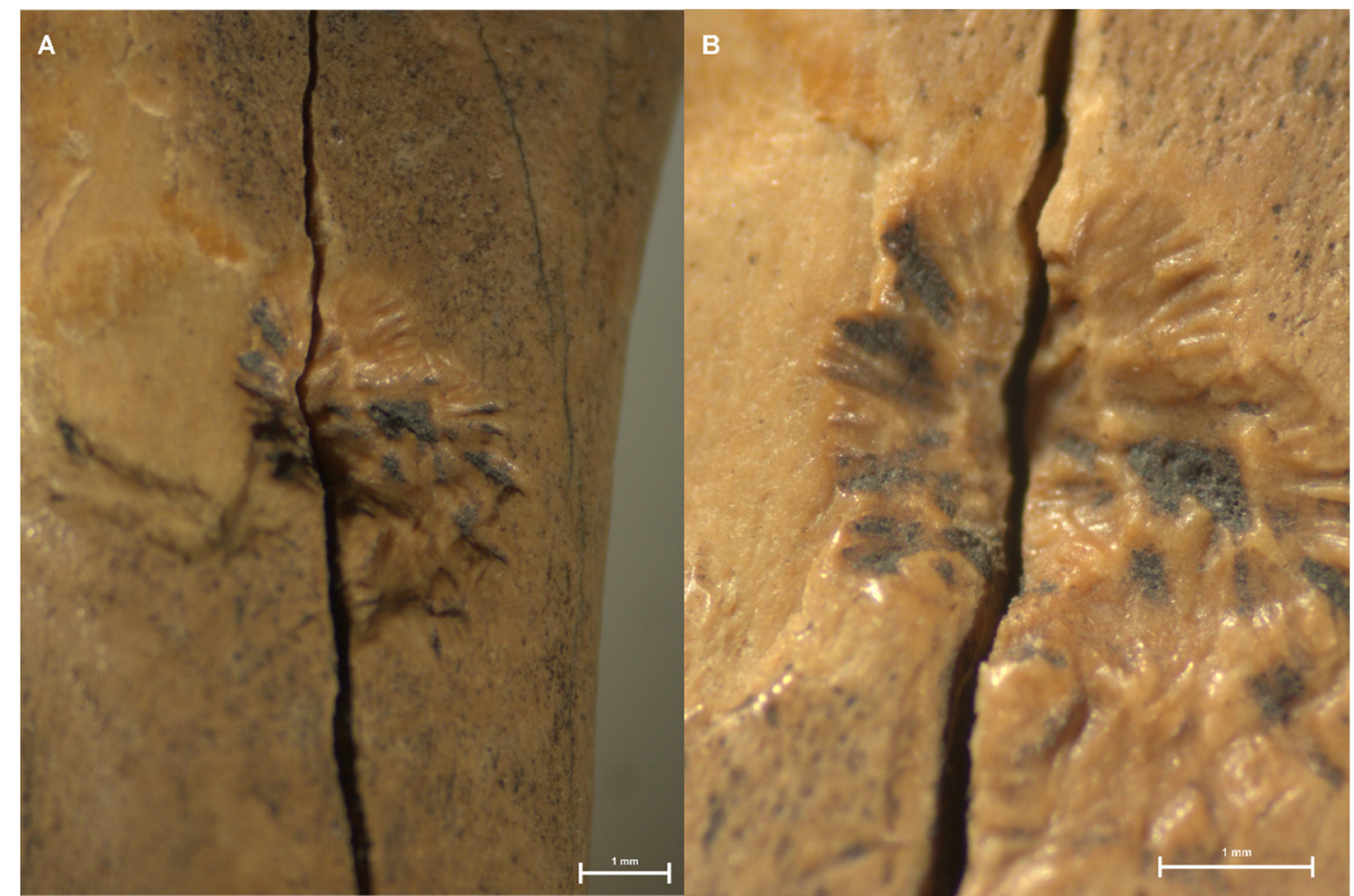

Figure 6. (A) Pits with emanating striae over the crack, pit with striae in base, and striations on coypu's humerus (Id. 1623). (B) Details of the traces and the crack.

In some cases, the pits penetrate profoundly the cortical bone. On a coypu's tibia (Id. 5773), there is a pit with emanating striae on its distal diaphysis. It is formed by multiple striations radially arranged around a deep center (Figure 4B). Notably, we identified pits that combined attributes, such as the trace displayed on the cortical surface of a coypu humerus (Id. 5332). This is composed of numerous parallel and sub-parallel striations radiating from around the outer circumference of a shallow cavity. The last one has several random grooves that overlap each other (Figure 7A,B).

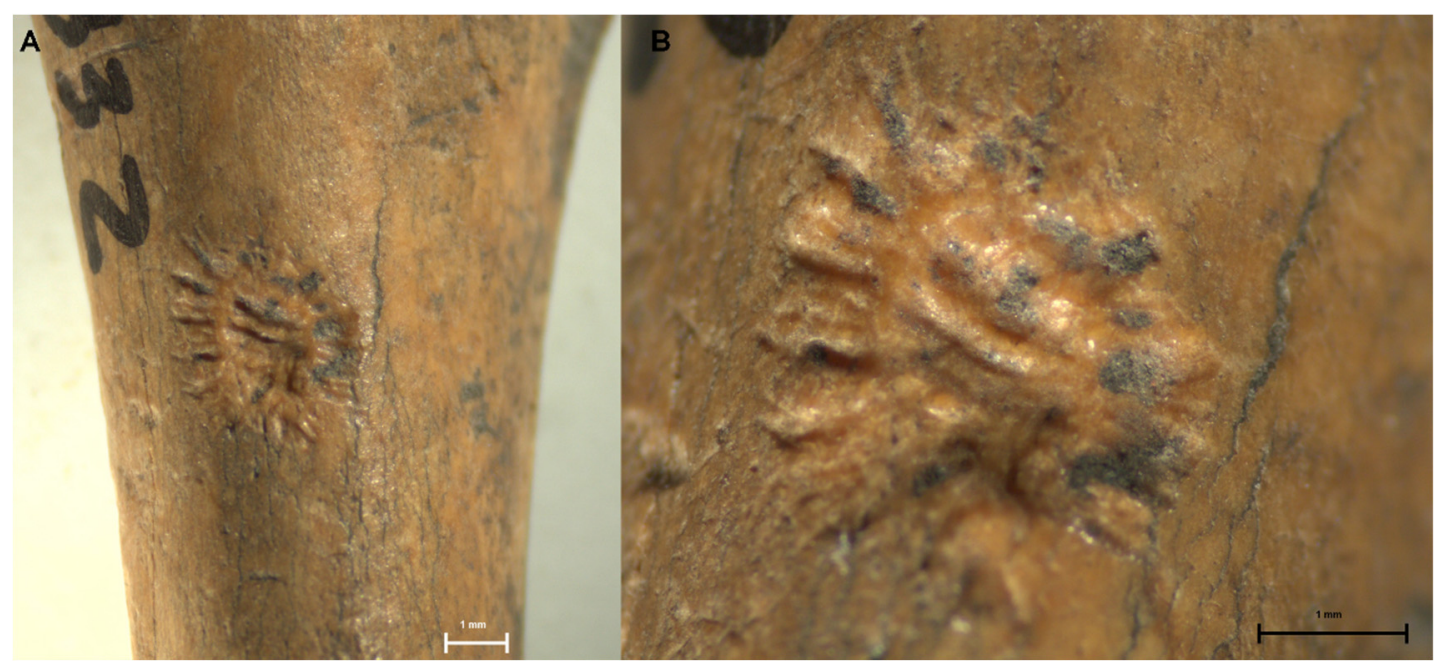

Figure 7. (A) Pit with emanating striae and striae in base on coypu's humerus (Id. 5332). (B) Details of the traces.

One remarkable issue is the record of this type of traces on weathered bird bones: the previously mentioned (Id. 205) and the shaft of a femur (Id. 220), which displays a pit with a smooth central cavity that has faint striations. Next to this trace, there are numerous 
sub-parallel striations (a few of them overlapped). It also has brown residue spots on the cortical surface. However, the area affected by the grooves that compose the marks is remarkably lighter, which means that the cracks produced by weathering are previous to the traces (Figure $4 \mathrm{~A}$ ).

Numerous striations were observed, being more frequent in LG5 (LG1 $\mathrm{n}=1$; LG5 $\mathrm{n}=7$ ) (Figure 2). They usually appeared overlapping (Figure 8A); and in specimen Id. 14, the affected area is crossed by a fissure that runs longitudinally along the bone. Besides, on specimen Id. 5 from LG1, grooves are parallelly disposed and transversely orientated around the edge of a nutrient foramen. These marks are visible to the naked eye and the affected sector measured $4.89 \mathrm{~mm}$ (Figure $8 \mathrm{~B}$ ). In general, this type of damage occurs associated with other traces such as pits. One example is a femur of guinea pig (C. aperea; Id. 3713) that shows a surface pit with overlapped striations in its base and a few parallel striations besides it (Figure 3A), on the proximal sector of the bone's shaft.

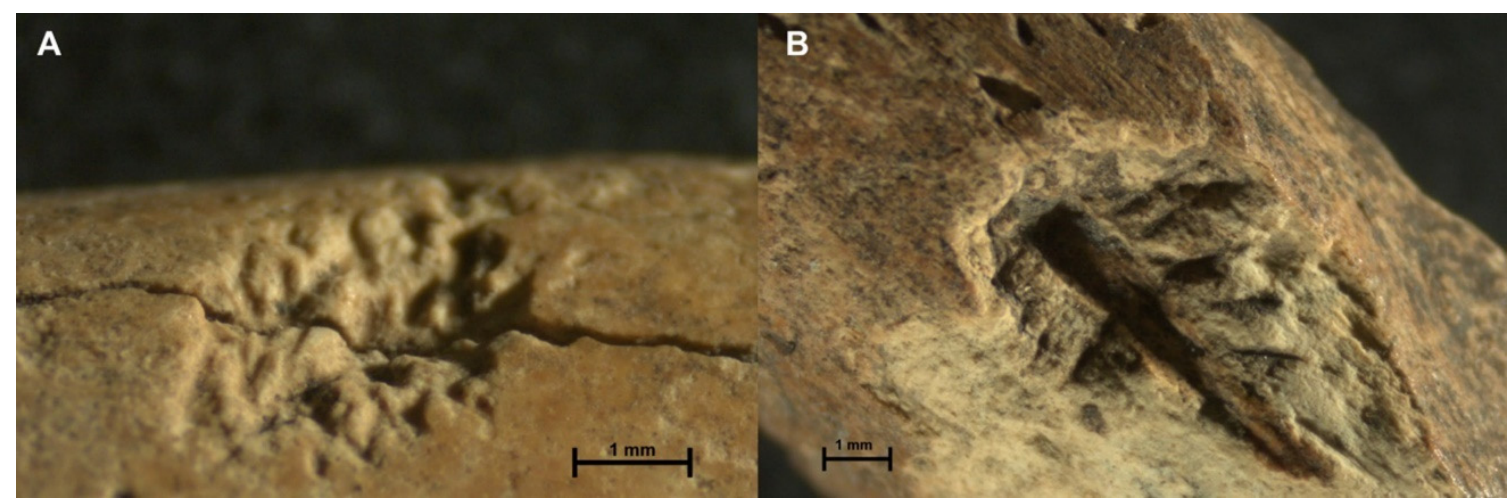

Figure 8. (A) Striations on deer's humerus (Id. 14). (B) Striations around a nutrient foramen (Id. 5).

We recorded a bore and two circular holes on big mammal bones from LG1 (NISP = 2). The first phalange of pampas deer (O. bezoarticus; Id. 362) has a bore (Figure 9A) measuring $2.93 \mathrm{~mm}$ in diameter. It is located on the distal end of the phalange and penetrates the bone through to the medullary cavity. Besides, we observed the removal of outer lamellae around its edge and the exposure of the underlying bone structure. The other two holes have smooth bases, and their diameters are $4.06 \mathrm{~mm}$ and $2.66 \mathrm{~mm}$ (Figure 9B,C). One of them (Id. 4) shows a pit with striae in base next to the deep hole.

The etched appearance is another type of surface damage observed on scarce fragmented bones from La Guillerma sites. We observed it surrounding the aforementioned bore (Id. 362; Figure 9A) and around pits in Id. 2005 and Id. 201, exposing the underlying bone structure (Figures 3B and 10A,B).

Finally, the surface coating was also recorded in association with other traces. In a specimen from LG1, this modification is present as a dark brown coating that coloured the bone and is combined with etching around a pit (Id. 201, Figure 10), while a bird's femur (Id. 220, Figure 4A) has a brown coating that discoloured the cortical surface. 


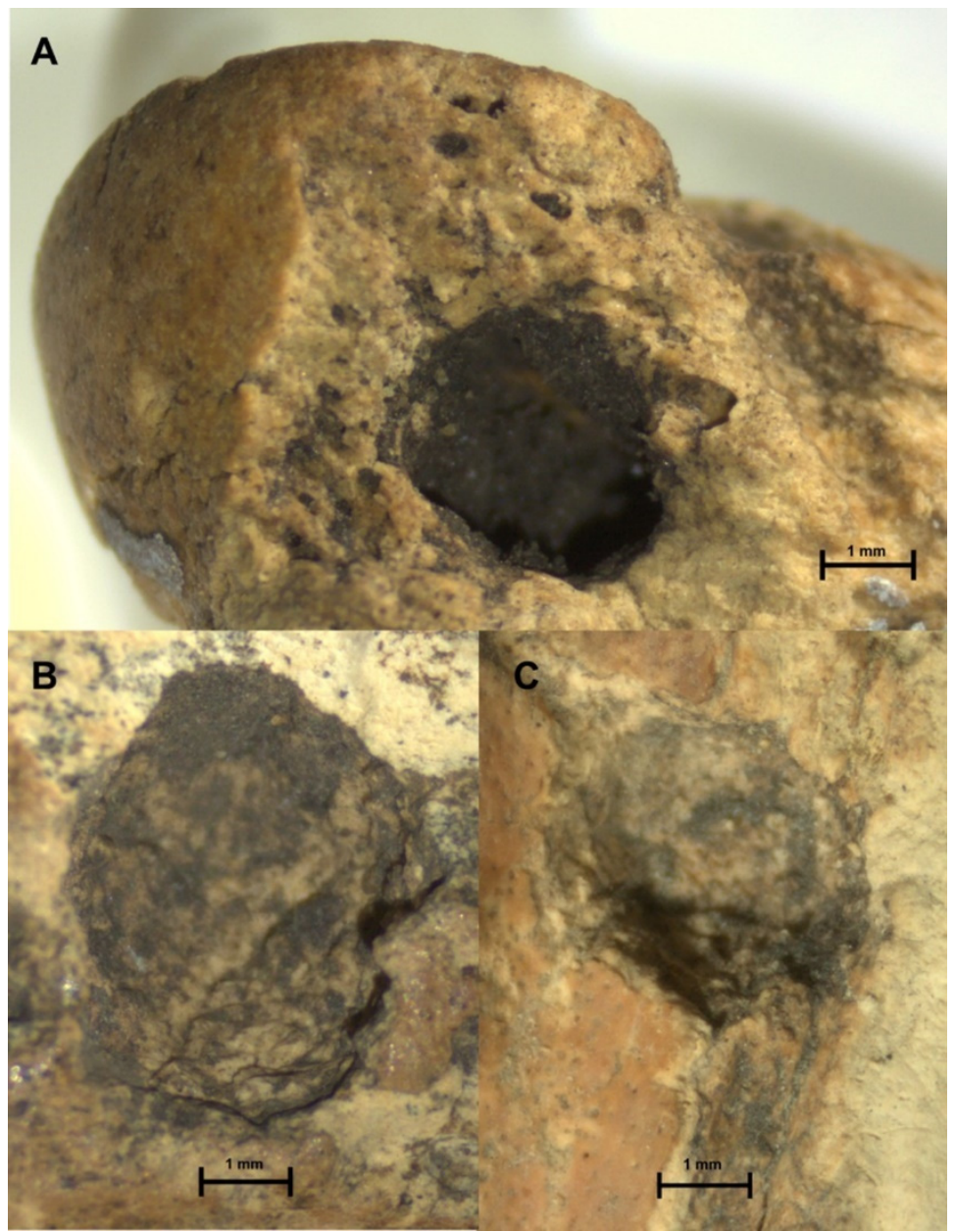

Figure 9. (A) Borehole on phalange and etched surface around it (Id. 362). (B) Hole on a long bone fragment (Id. 4). (C) Hole on a deer's tibia (Id. 217).
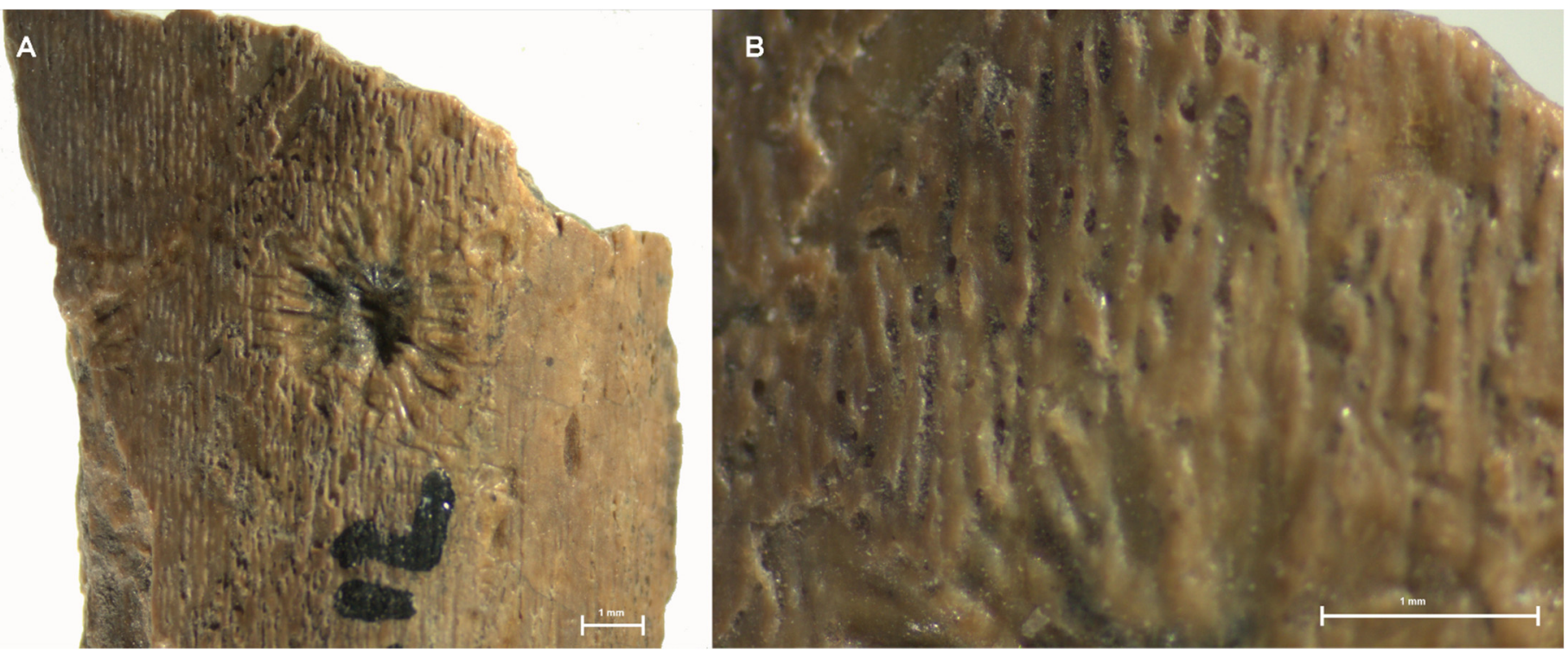

Figure 10. (A) Pit with emanating striae and surface coating with removal of outer lamellae (Id. 201). (B) Detail of the etched appearance. 


\section{Discussion}

As a result of our study, we identified seven types of modifications associated with insect activities: pits with striae in base, pits with emanating striae, bore/tube, holes, striations, etched appearance, and surface coating/discolouring. Now we will discuss each of these types, their possible etiology, and their implications for the integrity of the osteoarchaeological assemblage of La Guillerma. In the first place, both pits with striae in base and with emanating striae were recorded by Backwell and co-authors [14] in their experimental observation of trogid beetles. On the contrary, they were not observed during actualistic research with termite species Odontotermes badius. However, the authors suggested that the lack of pits with striae and furrowing could be related to the length and time of exposure; they conducted the experiment in winter when the insects were less active. In this sense, in a previous research project, Backwell and collaborators [6] registered that Trinervitermes trinervoides (after six months of trial) had generated surface pits (semi-circular depressions with radially arranged edge gnawing that comprised overlapping individual sub- and parallel striations) and star-shaped marks (several individual grooves radially arranged around a cavity with smooth walls). Parkinson [32] also identified three types of surface pits on bones after a set of experiments with Dermestes maculatus: (1.) highly variable shallow depressions with striations radiating around the outer circumference; (2.) semi-circular shallow depressions with randomly orientated striations over them; and (3.) irregular shaped depressions not associated with gnawing striations. Likewise, Holden et al. [35] recorded small and medium circular pits with concave bases that were created by the same insect.

With respect to the traces' depth, one of the deep pits (Id. 1623) had a fissure across it. Pomi and Tonni [37] also recorded insect traces lying over cracks on the bones and proposed that the marks were developed after the opening of the cracks. Rather, in our case, we believe that the insect chewing could have weakened the bone, making it more prone to fragmentation by other taphonomic agent or process (e.g., roots, burrowing animals), and thus generating a deep crack. We support this idea on the basis that the recorded striations seem to be cut by the crack, but they continue on each side. Otherwise, trace's depth is a variable that could be related to the presence of soft or desiccated tissues at the moment of trace's construction [8,11]. Another pit with emanating striae on a coypu bone (Id. 5773) has a deeper centre that could have been produced while anchoring an apical tooth. On this matter, Backwell et al. [6], after observing signs of wear damage on the medial side of the apical tooth of T. trinervoides worker mandibles, proposed that "star-shaped marks radiate around a well-defined central cavity that provides anchorage for one half of the mandible, while the other half excavates the bone using an inward gesture" [6] (p. 83). These authors observed that $T$. trinervoides' mandibles are asymmetrical, with a single apical tooth that produces individual striations. In this sense, Britt and collaborators [7] proposed that the parallel grooves were generated by Dermestidae since their mandibles had two widelyspaced apical teeth. Nonetheless, Holden et al. [35] registered that larval Tenebrionidae had similar mandibles with two apical teeth. Therefore, they assert that mandibular marks are difficult to assign since tooth structure may be similar among families and vary between genera and species.

Some authors suggest that different traces represent transitional morphotypes [7,41]. Therefore, if the activity of the insect had continued, pits would have become holes or boreholes. For that matter, Backwell et al. [6] considered that star-shaped marks and surface pits were probably incipient boreholes made by termites searching for lipids. These features were macroscopically visible in their analysis, ranging between 3.41 and $4.20 \mathrm{~mm}$ in length and between 2.83 and $2.64 \mathrm{~mm}$ in width (with the exception of a borehole that measured 6.09 by $3.06 \mathrm{~mm}$ ) and holes with diameters between 1.54 and $3.63 \mathrm{~mm}$. For $D$. maculatus, there is a variable register of sizes in different experiments. Those infrequent boreholes recorded by Parkinson [32] tended to be elliptical and small (less than $0.68 \mathrm{~mm}$ long). Thus, the author asserted that they probably represent surface pits created by larvae which penetrated into the cortical and trabecular bone, then into the medulla. Their 
distribution would be related to the exploitation of haversian canals and marrow access and are not connected to the creation of pupal chambers. Holden et al. [35] registered bores that ranged between 2.5 and $3.5 \mathrm{~mm}$ in diameter after their live experiments with dermestids. Also, Zanetti et al. [42,43] documented that D. maculatus feeds on bone and in the process generates diverse traces (e.g., spherical or ovoid depressions for refuge and pupation). They observed that, in some cases, the largest marks measure more than one centimeter.

Regarding bore and holes, the unique bore recorded in the sample perforates the bone through to the medullae channel on the distal end of a deer phalange. This trace and the two holes range ca. 2.7 to $4.1 \mathrm{~mm}$ in diameter. Taking these measures into account, the diameters of bores and holes generated by dermestids and termites overlap. Those recorded on La Guillerma sample have a range of sizes that are consistent with those registered by the other researchers $[6,35]$ for both termites and dermestids, so this data would not allow us to attribute the modification to one or the other of these agents. In relation to the site of emplacement, Backwell and co-authors [6] observed a similar result during the experimental research with termites, as they discerned a predominance of boreholes on proximal or distal ends. However, Parkinson [32] noted that marks produced by dermestids tended to be located either on the epiphysis or close to the diaphysisepiphysis junction and not on the dense cortical bone areas. Thus, these two types of marks that we have registered in La Guillerma could have been generated by different insects or, as Parkinson [11] remarks, by the same insect in different larval developmental stages. Besides, they could also be a consequence of different behaviours (feeding or pupation), but it would be too speculative to state one of them from such a small sample.

Striations are more frequent in our sample, especially as individually discernible traces. They are considered as the early forms of bone destruction [6]. We highlight the case of a bone fragment from LG1 that displays parallel striations around a nutrient foramen (Id. 5). Britt and co-authors [7] proposed that the concentration of traces around nutrient foramina represent attempts to widen the opening. They interpreted that these areas and articular bones were bored to consume marrow. They also suggested that the insects may have consumed the cartilage and ligaments of articular ends prior to bone consumption. Nevertheless, the modification of bones by dermestids would not be exclusively related to diet. It could be a consequence of the exploration of available ways for the creation of pupation chambers, a frequent behaviour in insects [32]. Holden et al. [35] observed that larvae of both dermestids and tenebrionids expanded foramina. In the case of termites, gnawing around vascular canals would have provided traction for the apical teeth [6].

Additionally, we observed the etched surface appearance on three mammal bones (LG1 = 2; LG5 = 1) that exposed the underlying bone structure. Backwell et al. [6] mentioned, after their experiments with termites, that this acid-etched appearance is a result of their saliva or faecal rich material. But this damage was also recorded on experiments with trogid beetles [14]. We discerned the combination of etched bone with surface residue on a bone fragment from LG1 (Id. 201). However, we distinguished this dark brown coating on another avian bone from LG5 (Id. 220). Noteworthy, we did not recognize the latter as an isolated trace but rather we emphasise the difficulty to identify it on assemblages that are affected by manganese stains or burning that could obliterate this residue or make researchers misinterpret it $[6,32]$. The discolouration of the bone surface was also stated by Parkinson [32] as an evidence of P. americana's action, although it was not associated with other damages on cortical bones.

We emphasise the presence of patches and lineation of traces (e.g., on two areas of Id. 205). According to Britt et al. [7], the former corresponds to foraging areas and the latter represents galleries. Those authors also mentioned, referring to termites, that "the large pits are composites of small pits related to broad surface foraging/mining" [7] (p. 65); so, they do not represent the size of the tracemaker. In this sense, within our sample, we frequently recognized the overlapping of multiple traces as grooves or pits. 
As insects can access carcasses at different stages of decay, it has also been observed that termites and dermestids alter fresh, dry, weathered and fossilized bones [6,14,32]. Our analysis points to the action of insects on different bone stages: two avian bones distinctly display evidence of light weathering over the cortical surface except on traces. Moreover, Zanetti and co-authors [43] found that dermestids consumed and marked burned tissues. The selection of bones at different diagenetic stages could be related to the consumption of various trace elements (calcium, phosphorus and nitrogen), proteins and lipids [6].

In summary, insect traces recorded on LG1 and LG5 result in both surficial bioerosion and modification of trabecular bone. Additionally, we recognized the two types of bioerosion by insects on bones mentioned by Huchet [44]: mechanical, produced by the action of the mandibles (striations, pits), and chemical (etched surfaces), caused by proteolytic enzymes contained in digestive juices.

\section{Assessing Different Tracemakers}

In reference to the tracemaker, diverse studies point out equifinality problems and suggest considering a set of modification types, their association, frequency and distribution patterns e.g., $[6,11,32,41]$. Although our sample is composed of few specimens with insect traces, we can make some comments in this regard. In this preliminary research we recorded macroscopically visible marks such as pits, holes and striations. A microscopic approach showed more details of traces that are composed by other marks (e.g., pits with striae in base).

To evaluate termites as possible tracemakers, we considered their presence in the study area both in past and present times. In Buenos Aires, there is a register of termites from the late Pliocene to the middle Pleistocene $[45,46]$. To date, three species have been identified in the northeastern sector of this province: Rugitermes rugosus, Anoplotermes meridianus and Anoplotermes cingulatus [47]. The first one belongs to Kalotermitidae, which nest directly within their food source and consume mainly drywood; the second and third correspond to Termitidae, which are subterranean. A. cingulatus feeds on decomposing wood and soil, while A. meridianus eats humus and dry grass and leaves [47]. Both locate food sources as they dig a network of tunnels and prefer fine-grained soils since they facilitate excavation [38]. This is consistent with the soils' texture of La Guillerma [18].

Regarding termites' traces, we recognized pits with emanating striae that resembled star-shaped marks, previously associated with termites' action [6,10,44]. The presence of surface coating as a residue (probably made of faecal matter, earth, wood, and saliva [14,36]) and bone decoloring around it may support the identification of this bonemarker. However, in addition to our small sample, we did not find termite mounds, carton-lined tunnels, chambers or fossil nests in the study area. Laza [46] proposed that the cold climatic trend that occurred by the late Pleistocene would have forced the retraction of termites towards the north of Buenos Aires. Since then, their activity has been limited and that could be the cause of their absence. Nonetheless, the warmer conditions of the late Holocene [22,23] should have reactivated the action of termites, so it cannot be ruled out.

To contemplate dermestids as a potential tracemaker, we considered Parkinson's mention that, "the co-occurrence of surface tunnelling, destruction of bone, infrequent bore holes, surface pits of varying classes and broad areas of gnawing striations can be used as an indicator of D. maculatus activities" [32] (p. 139). In this sense, Backwell et al. [14] emphasize that hide beetles produce invasive edge gnawing. We did not identify surface tunnelling or large areas of edge gnawing. Regarding the latter, we only recorded foraging areas (sensu Britt et al. [7]) conformed by overlapping of pits.

In the experiment with trogid beetles and O. badius, Backwell and collaborators [14] found that the former insects caused more destruction and made more boreholes on the bones. In addition, dermestids' holes and boreholes are frequently described with a tendency to be ovoid or elliptical (e.g., [14,32]). Having in mind that the holes and the bore identified in LG1 specimens are round and their ranges both in size and shape as isolated traces, we could consider termites as the possible causal agent. However, in two 
cases the marks are associated with other traces: the bore is surrounded by etched surface (a trait that Backwell et al. [14] register in more proportion in termites). However, a hole is clustered with a pit with striae in base (that these same authors only recorded in their experiment with dermestids). Then, based on this inconclusive evidence and the fact that our sample is too small, we cannot propose a unique causal agent.

The attribution of a specific tracemaker permits palaeoecological reconstruction based on geographic distribution and climate requirements. However, this is a difficult task if no comparative material from actualistic experiments is available [35]. In this sense, further research on different carcass-exploiting insects will help infer tracemakers. Although we cannot make thorough interpretations on past ecology and climate, as Farina and Cicchino [34] state, there is a good entomological resilience to flood pulses in the coastal system of Buenos Aires province, which is close to our study area. Thus, these events would not have significantly affected its insects' ecology and population.

There were different moments in which insects could have had access to bone remains. They could consume the bones when they were above ground, still having tissues and medulla. However, they could also mark those remains after having been exposed to environmental conditions. If the agent had subterranean habits (such as Termitidae), it could have affected bones within the soil.

As it was registered on experimental studies (e.g., [6]) and inferred in taphonomic analyses (e.g., [10]), termites can generate preservation biases and, in consequence, alter the representation of skeletal elements and make taxonomic identification more difficult. Also, the modifications produced by D. maculatus usually concentrate on epiphysis and the diaphysis-epiphysis junction. Therefore, they can promote increasing separation and fragmentation of elements, which may eventually result in their destruction. Although gnawing of dense bone by dermestids is not prolific, they can destroy small bones (particularly of Aves) within a short period [48]. P. americana and T. trinervoides also do significant damage to bird bones [6,32]. Hence, insects may at least partially affect the representation of Aves in archaeological and palaeontological sites.

We believe that the actions of insects could have created biases, for instance, if we take into account that the holes and bore are present in large and thicker mammal elements, and that they were not documented neither in bird bones nor in medium to small rodent bones. On the other hand, as referred in one of the cracked elements, the mark could have weakened the bone making it more prone to fracture. We cannot rule out that in smaller or weaker bones the destruction could have been greater.

Since 1988, we have developed different studies on the faunal assemblage from La Guillerma archaeological locality. As a result, we were able to comprehend the role of people and nature as agents on the accumulation and modification of bone remains $[16,18,26]$. The analysis presented here has allowed us to identify for the first time the action of insects on sites from the Salado River Depression. Our approach contributes to increasing the background of this type of bioerosion in archaeological and palaeontological sites from Argentina (i.e., [12,37]).

Overall, this analysis has shed light on a taphonomic agent that had not been thoroughly addressed and for which there is little background in Argentina. We are still unable to assert which insect or insects were the tracemakers of the bones from La Guillerma sites and therefore to make palaeoecological interpretations. Nonetheless, we have identified a natural formation process that may have introduced variability in the archaeofaunal record and even produce destruction of organic materials such as bone. In this regard, diverse agents and processes were involved in La Guillerma shallow sites' formation. However, concerning the specificity of this kind of sites, we are not able to make statements about the incidence of insects on soil characteristics or to distinguish different deposition events yet. We had previously recorded the action of edaphic fauna and roots that altered the disposition of archaeological remains within the soil and we had also identified weathering and manganese stains on bone surfaces [16,18,24,26,49]. Moreover, the cultural formation processes also played a role as the hunter-gatherer-fisher groups used to resettle period- 
ically in these sites over the centuries $[15,16,18]$. Hence, the bioturbation produced by insects is one more factor, among others, that contributed to the forming of the shallow archaeological sites of the study area.

Finally, we are aware that experimental analyses are required to improve our knowledge of insect traces and to establish useful criteria to determine causal agents. In this sense, documenting modern analogues will offer unequivocal data to link modification types to specific taphonomic processes and agents [2,11]. Also, a future analysis of our sample through higher magnification equipment will improve the accuracy of our identifications.

\section{Final Remarks}

The identification of insects (directly or indirectly) in an archaeological context improves the interpretation of bioturbation processes since they can affect as well as displace artifacts or ecofacts from their original context. In addition, insect-produced damage to bone surfaces can obliterate cultural evidence and other formation processes. They are also useful to make palaeoecological interpretations.

Our research provided a better understanding of the faunal assemblages from La Guillerma sites, since it allowed us to identify and analyze a novel taphonomic agent in the area. Despite this type of marks being scant, we should consider potential biases that insects could have produced on bone remains. Moreover, they could also modify the soil structure adding their action to other taphonomic agents such as earthworms [49]. We encourage considering insects in the study of other archaeological sites in the pampas as well as other Argentinian regions.

To improve our interpretation of traces and identification of uncommon taphonomic agents, such as insects, the development of actualistic studies is imperative. For this reason, we are starting experimental research that includes Coleoptera (D. maculatus) and local termites (Cortaritermes cumulans).

Author Contributions: Conceptualization, P.D.E. and A.E.F.; methodology, P.D.E., A.E.F. and M.I.G.; formal analysis, P.D.E., A.E.F. and M.I.G.; investigation, P.D.E., A.E.F. and M.I.G.; writing—original draft preparation, P.D.E., A.E.F. and M.I.G.; writing—review and editing, P.D.E., A.E.F. and M.I.G.; project administration, M.I.G.; funding acquisition, P.D.E. and M.I.G. All authors have read and agreed to the published version of the manuscript.

Funding: This research was funded by Agencia Nacional de Promoción Científica y Tecnológica, grants PICT-2015-0272 and PICT-2016-0368, and by Secretaría de Ciencia y Técnica, Universidad de Buenos Aires, grant UBACyT-2018-20020170100525BA.

Data Availability Statement: Data are contained within the article and are available on request from the corresponding author.

Acknowledgments: We thank Roxana Mariani, Eduardo Tonni, José Laza, Jean-Bernard Huchet and Jorge Genise for helping us with their knowledge on insect traces; Enrique Laffont and Juan Manuel Coronel for providing us with useful bibliography; Olivia Sokol for drawing the map; Marcelo Zárate for his observations regarding palaeoenvironment; Romina Frontini and Mónica Salemme for their comments on a previous draft. We also thank the three anonymous reviewers for their constructive comments. The authors are the only responsible for the arguments discussed in this paper.

Conflicts of Interest: The authors declare no conflict of interest. The funders had no role in the design of the study; in the collection, analyses, or interpretation of data; in the writing of the manuscript; or in the decision to publish the results.

\section{References}

1. Corron, L.; Huchet, J.B.; Santos, F.; Dutour, O. Using Classifications to Identify Pathological and Taphonomic Modifications on Ancient Bones: Do "Taphognomonic" Criteria Exist? Bull. Mem. Soc. Anthropol. Paris 2017, 29, 1-18. [CrossRef]

2. Fernandez-Jalvo, Y.; Andrews, P. Atlas of Taphonomic Identifications. Vertebrate Paleobiology and Paleoanthropology; Springer: Dordrecht, The Netherlands, 2016; pp. 155-166. [CrossRef]

3. Lyman, R.L. Vertebrate Taphonomy; Cambridge University Press: Cambridge, UK, 1994. 
4. Tomassini, R.L.; Montalvo, C.I.; Ezquiaga, M.C. The oldest record of flea/armadillos interaction as example of bioerosion on osteoderms from the late Miocene of the Argentine Pampas. Int. J. Paleopathol. 2016, 15, 65-68. [CrossRef] [PubMed]

5. Zonneveld, J.-P.; AbdelGawad, M.K.; Miller, E.R. Ectoparasite borings, mesoparasite borings, and scavenging traces in early Miocene turtle and tortoise shell: Moghra Formation, Wadi Moghra, Egypt. J. Paléontol. 2021, 1-19. [CrossRef]

6. Backwell, L.R.; Parkinson, A.H.; Roberts, E.M.; D'Errico, F.; Huchet, J.-B. Criteria for identifying bone modification by termites in the fossil record. Palaeogeogr. Palaeoclim. Palaeoecol. 2012, 337-338, 72-87. [CrossRef]

7. Britt, B.B.; Scheetz, R.D.; Dangerfield, A. A Suite of Dermestid Beetle Traces on Dinosaur Bone from the Upper Jurassic Morrison Formation, Wyoming, USA. Ichnos 2008, 15, 59-71. [CrossRef]

8. Huchet, J.-B.; Le Mort, F.; Rabinovich, R.; Blau, S.; Coqueugniot, H.; Arensburg, B. Identification of dermestid pupal chambers on Southern Levant human bones: Inference for reconstruction of Middle Bronze Age mortuary practices. J. Archaeol. Sci. 2013, 40, 3793-3803. [CrossRef]

9. Huchet, J.-B.; Greenberg, B. Flies, Mochicas and burial practices: A case study from Huaca de la Luna, Peru. J. Archaeol. Sci. 2010, 37, 2846-2856. [CrossRef]

10. Matu, M.; Crevecoeur, I.; Huchet, J.-B. Taphonomy and Paleoichnology of Olduvai Hominid 1 (OH1), Tanzania. Int. J. Osteoarchaeol. 2017, 27, 785-800. [CrossRef]

11. Parkinson, A.H. Traces of Insect Activity at Cooper's D Fossil Site (Cradle of Humankind, South Africa). Ichnos 2016, 23, 322-339. [CrossRef]

12. Di Donato, R.M. Taphos nomos: El potencial de la tafonomía en la interpretación de contextos funerarios. In Mamül Mapu: Pasado y Presente desde la Arqueología Pampeana; Berón, M.A., Luna, L.H., Bonomo, M., Eds.; Libros del Espinillo: Ayacucho, Argentina, 2010; pp. 137-152.

13. Wrobel, G.D.; Biggs, J. Osteophageous insect damage on human bone from Je'reftheel, a Maya mortuary cave site in west-central Belize. Int. J. Osteoarchaeol. 2018, 28, 745-756. [CrossRef]

14. Backwell, L.; Huchet, J.-B.; Jashashvili, T.; Dirks, P.H.; Berger, L.R. Termites and necrophagous insects associated with early Pleistocene (Gelasian) Australopithecus sediba at Malapa, South Africa. Palaeogeogr. Palaeoclim. Palaeoecol. 2020, 560, 109989. [CrossRef]

15. Frère, M.M.; González, M.I.; Greco, C. Continuity in the Use of Shallow Sites of the Salado River Basin in the Pampean Region, Argentina. Radiocarbon 2016, 58, 921-933. [CrossRef]

16. González, M.I.; Escosteguy, P.D.; Salemme, M.C.; Frère, M.M.; Weitzel, C.; Vecchi, R. Assessing Strategies for Coypu Hunting and Use in the Salado River Depression (Buenos Aires Province, Argentina); Springer: Singapore, 2021; pp. 59-81.

17. González, M.I.; Frère, M.M. Río Salado: Espacio de interacción de cazadores-recolectores-pescadores (provincia de Buenos Aires, Argentina). Rev. Mus. La Plata 2019, 4, 611-632. [CrossRef]

18. González, M.I. Arqueología de Alfareros, Cazadores y Pescadores Pampeanos. Colección de Tesis Doctorales; Sociedad Argentina de Antropología: Buenos Aires, Argentina, 2005.

19. López, H.L.; Baigún, C.R.M.; Iwaszkiw, J.M.; Delfino, R.; Padín, O.H. La Cuenca del Salado: Uso y Posibilidades de sus Recursos Pesqueros. Portal de Libros de la Universidad Nacional de La Plata; Editorial de la Universidad Nacional de La Plata: Buenos Aires, Argentina, 2001.

20. Quirós, R.; Rennella, A.M.; Boveri, M.B.; Rosso, J.J.; Sosnovsky, A. Factores que afectan la estructura y el funcionamiento de las lagunas pampeanas. Ecol. Austral. 2002, 12, 175-185.

21. Zárate, M.A. El paisaje pampeano a través del tiempo. In Mamül Mapu: Pasado y Presente desde la Arqueología Pampeana; Berón, M.A., Luna, L.H., Bonomo, M., Eds.; Libros del Espinillo: Ayacucho, Argentina, 2010; pp. 19-32.

22. Pommarés, N.N.; Fucks, E.E.; Pisano, M.F.; Luengo, M.S.; Ramos, N.A.; Di Lello, C.V. Late Pleistocene-Holocene paleoenvironments in the middle basin of the Salado river, province of Buenos Aires, Argentina. J. S. Am. Earth Sci. 2021, $105,103001$. [CrossRef]

23. Fucks, E.E.; Pisano, F.; Carbonari, J.; Huarte, R. Aspectos geomorfologicos del sector medio e inferior de la Pampa Deprimida, provincia de Buenos Aires. Rev. Soc. Geológica España 2012, 25, 107-118.

24. Zárate, M.A.; de Bonaveri, M.I.G.; Flegenheimer, N.; Bayón, C. Sitios arqueológicos someros: El concepto de sitio en estratigrafía y sitio de superficie. Cuad. Inst. Nac. Antropol. Pensam. Latinoam. 2000, 19, 635-653.

25. Behrensmeyer, A.K. Taphonomic and ecologic information from bone weathering. Paleobiology 1978, 4, 150-162. [CrossRef]

26. Escosteguy, P. Etnoarqueología de Nutrieros. Una Propuesta Metodológica Aplicada al Registro Arqueológico de la Depresión del Salado y del Noreste de la Provincia de Buenos Aires; Universidad de Buenos Aires: Buenos Aires, Argentina, 2011.

27. Escosteguy, P.D.; Salemme, M.; González, I. Myocastor coypus ("coipo", Rodentia, Mammalia) como recurso en los humedales de la Pampa bonaerense: Patrones de explotación. Rev. Mus. Antropol. 2012, 5, 13-30. [CrossRef]

28. Escosteguy, P.D.; González, M.I.; Salemme, M.C. Aprovechamiento de venado de las pampas y ciervo de los pantanos en la Depresión del río Salado (región pampeana, Argentina). In Libro de Resúmenes del IV Encuentro Latinoamericano de Arqueo-Zoología (ELAZ). Homenaje al Dr. Luis A. Borrero; Cruz, I., Ed.; UNPA Edita: Río Gallegos, Argentina, 2018; pp. $133-134$.

29. Genise, J.F.; Mángano, M.G.; Buatois, L.A.; Laza, J.H.; Verde, M. Insect Trace Fossil Associations in Paleosols: The Coprinisphaera Ichnofacies. Palaios 2000, 15, 49-64. [CrossRef]

30. Wood, W.R.; Johnson, D.L. A survey of disturbance processes in archaeological site formation. In Advances in Archaeological Method and Theory; Schiffer, M.B., Ed.; Academic Press: Cambridge, MA, USA, 1978; Volume 1, pp. 315-381. 
31. McBrearty, S. Consider the humble termite: Termites as agents of post-depositional disturbance at african archaeological sites. J. Archaeol. Sci. 1990, 17, 111-143. [CrossRef]

32. Parkinson, A.H. Dermestes Maculatus and Periplaneta Americana: Bone Modification Criteria and Establishing Their Potential as Climatic Indicators; University of the Witwatersrand, Johannesburg: Johannesburg, South Africa, 2012.

33. Cigliano, M.M.; Melo, M.C.; Montemayor, S.I.; del Río, M.G.; Dellapé, P.M. BiodAr—Biodiversidad de Insectos de la Argentina y Uruguay. Available online: https:/ / biodar.unlp.edu.ar/ (accessed on 5 April 2021).

34. Farina, J.; Cicchino, A. Una excursión entomológica por la costa atlántica bonaerense. In La Costa Atlántica de Buenos Aires. Naturaleza y Patrimonio Cultural; Athor, J., Celsi, C., Eds.; Fundación de Historia Natural Félix de Azara: Buenos Aires, Argentina, 2016; pp. 281-323.

35. Holden, A.R.; Harris, J.M.; Timm, R.M. Paleoecological and Taphonomic Implications of Insect-Damaged Pleistocene Vertebrate Remains from Rancho La Brea, Southern California. PLoS ONE 2013, 8, e67119. [CrossRef]

36. Huchet, J.; Deverly, D.; Gutierrez, B. Taphonomic evidence of a Human skeleton gnawed by termites in a Mochecivilisation grave at Huaca de la Luna, Peru. Int. J. Osteoarchaeol. 2011, 21, 92-102. [CrossRef]

37. Pomi, L.H.; Tonni, E.P. Termite Traces on Bones from the Late Pleistocene of Argentina. Ichnos 2011, 18, 166-171. [CrossRef]

38. Torales, G.J. Biodiversidad de Artrópodos Argentinos: Una Perspectiva Biotaxonómica; Ediciones Sur: La Plata, Argentina, 1998.

39. Go, M. A Case of Human Bone Modification by Ants (Hymenoptera: Formicidae) in the Philippines. Forensic Anthr. 2018, 1, 117-123. [CrossRef]

40. Pirrone, C.A.; Buatois, L.A.; Bromley, R.G. Ichnotaxobases for bioerosion trace fossils in bones. J. Paléontol. 2014, 88, 195-203. [CrossRef]

41. Odes, E.J.; Parkinson, A.H.; Randolph-Quinney, P.S.; Zipfel, B.; Jakata, K.; Bonney, H.; Berger, L.R. Osteopathology and insect traces in the Australopithecus africanus skeleton StW 431. S. Afr. J. Sci. 2017, 113, 7. [CrossRef]

42. Zanetti, N.I.; Visciarelli, E.C.; Centeno, N.D. Taphonomic Marks on Pig Tissue Due to Cadaveric Coleoptera Activity Under Controlled Conditions. J. Forensic Sci. 2014, 59, 997-1001. [CrossRef]

43. Zanetti, N.I.; Ferrero, A.A.; Centeno, N.D. Depressions of Dermestes maculatus (Coleoptera: Dermestidae) on Bones Could be Pupation Chambers. Am. J. Forensic Med. Pathol. 2019, 40, 122-124. [CrossRef]

44. Huchet, J.B. Man-eating termites: Osteolytic lesions upon human skulls perpetrated by subterranean termites (Insecta: Isop-tera). In Proceedings of the III Meeting of the International Conference in Funerary Archaeoentomology (ICFAE), Bordeaux, France, 5 June 2019.

45. Genise, J.F. A fossil termite nest from the Marplatan stage (Late Pliocene) of Argentina: Paleoclimatic indicator. Palaeogeogr Palaeoclimatol. Palaeoecol. 1997, 136, 139-144. [CrossRef]

46. Laza, J.H. Termiteros del Plioceno y Pleistoceno de la provincia de Buenos Aires, República Argentina. Significación paleoambiental y paleozoogeográfica. Ameghiniana 2006, 43, 641-648.

47. Torales, G.J.; Coronel, J.M.; Laffont, E.R.; Fontana, J.L.; Godoy, M.C. Termite associations (Insecta, Isoptera) in natural or semi-natural plant communities in Argentina. Sociobiology 2009, 54, 383-437.

48. Kirkland, J.; Bader, K.; Kirkland, J.I.; Bader, K. Insect trace fossils associated with Protoceratops carcasses in the Djadokhta Formation (Upper Cretaceous), Mongolia. In New Perspectives on Horned Dinosaurs: The Royal Tyrrell Museum Ceratopsian Symposium; Ryan, M.J., Chinnery-Allgeier, B.J., Eberth, D.A., Ralrick, P.E., Eds.; Indiana University Press: Bloomington, IN, USA, 2010; pp. 509-519.

49. Escosteguy, P.; Fernández, A.E. The Effects of Bioturbation by Earthworms. Preliminary Results of an Actualistic Taphonomy Experiment. J. Taphon. 2017, 15, 11-17. 